\title{
Iridocyclitis in black Americans: association with HLA B8 suggests an autoimmune aetiology
}

\author{
ROBERT B. NUSSENBLATT ${ }^{1}$ AND KAMAL K. MITTAL ${ }^{2}$ \\ From the ${ }^{1}$ Clinical Branch, National Eye Institute, National Institutes of Health, Department of Health \\ and Human Services, and the ${ }^{2}$ Bureau of Biologics, FDA, Bethesda, MD 20205, USA
}

SUMMARY Histocompatibility (HLA) testing was performed on a total of 171 black Americans, 129 controls, and 42 patients with iridocyclitis. None of the patients had a history of rheumatological disease. The phenotype frequency of HLA B8 was greatly increased among patients than the control group (exact $p=0.0010$ ). Most striking was the almost identical phenotypic frequency of B27 found in patients and in the control group (exact $p=0.07087$ ). No HLA DR antigen in the patient group was found to be significantly raised when compared with controls. The HLA B8 associated disease was seen more in females, was bilateral and nongranulomatous, had no systemic disease associated with it, and left patients with visual handicap. The HLA B8 antigen has been associated with various entities of presumed autoimmune origin, and these data suggest that iridocyclitis, at least in blacks, may be of similar aetiology.

Genetically determined cell surface markers, particularly the antigens of the major histocompatibility complex (the HLA region), have provided basic as well as clinical researchers with a powerful tool to examine possible involvement of the immune system in the manifestation of certain diseases. ${ }^{1}$ Disease associations with certain HLA antigens have been repeatedly shown. One of the earliest associations reported was that of HLA B27 with ankylosing spondylitis ${ }^{23}$ as well as anterior uveitis ${ }^{4}$ in Caucasoids. Among Caucasoid patients with ankylosing spondylitis over $90 \%$ were reported as having B27, while among Caucasoid controls only $4-6 \%$ had B27. Of the above B27 positive patients approximately $30 \%$ also have an anterior uveitis. ${ }^{6}$ Among Caucasoid patients with anterior uveitis $50-55 \%$ have been reported as having B27; a large proportion of these also suffer from rheumatological disease. The increased incidence of B27 in other ocular inflammatory syndromes, including those associated with arthritic conditions, has not been shown, ${ }^{7-9}$ and a recent report did not find any significant phenotype deviations in South African blacks with acute anterior uveitis as compared with healthy controls..$^{10}$

Recently it has become possible to type for B cell alloantigens or HLA DR antigens. ${ }^{11}$ The HLA DR locus is thought to have an important role in cell-tocell interactions which regulate the host's immune

Correspondence to Robert B. Nussenblatt, MD, Building 10, Room 10N313, National Eye Institute, NIH, 9000 Rockville Pike, Bethesda, MD 20205, USA. response. ${ }^{12}{ }^{13}$ Certain studies have demonstrated $\mathrm{D}$ or DR locus associations with autiommune disease, ${ }^{14} 15$ while the relationship of DR antigens with ocular diseases has only recently begun to be investigated. ${ }^{16} 17$

We have investigated the phenotypic frequencies of HLA A, B, C, and DR antigens in black Americans who had recurrent iridocyclitis with no evidence of rheumatological disease. We have compared their antigen frequencies with those in an appropriate control group of healthy individuals. We report here a significant association between the HLA B8 antigen and this disease. This finding might shed light on the possible aetiology of the disease.

\section{Material and methods}

\section{CONTROLS AND PATIENTS}

A total of 171 unrelated black Americans, 129 controls, and 42 patients were studied. All controls were healthy normal volunteers. All patients were examined by at least 2 ophthalmologists. They all had a history and ocular evidence of iridocyclitis. Four of the patients also carried the diagnosis of sarcoidosis. These patients, as well as some patients with no evidence of systemic disease, were felt to have a granulomatous uveitis. This was based on the presence of lardaceous ('mutton fat') keratic precipitates which were seen before the initiation of therapy.

HLA TESTING

All controls and patients were tested for HLA A, B, 
Table 1 Phenotypic frequencies (PF) of the $H L A$ antigens of loci $A, B$, and $C$ in black Americans with and without iridocyclitis

\begin{tabular}{|c|c|c|c|c|}
\hline \multirow[b]{2}{*}{ HLA antigen } & \multicolumn{2}{|l|}{$P F(\%)$} & \multirow[b]{2}{*}{ Exact $p$} & \multirow[b]{2}{*}{ Relative risk $†$} \\
\hline & $\begin{array}{l}\text { Controls } \\
n=129\end{array}$ & $\begin{array}{l}\text { Patients } \\
n=42\end{array}$ & & \\
\hline \multicolumn{5}{|l|}{ HLA A } \\
\hline 1 & $8 \cdot 5$ & $14 \cdot 3$ & 0.3713 & $1 \cdot 8$ \\
\hline 2 & $33 \cdot 3$ & $23 \cdot 8$ & 0.3368 & 0.6 \\
\hline 3 & $22 \cdot 5$ & $7 \cdot 1$ & $0.0383 *$ & 0.3 \\
\hline 9 & 27.9 & $26 \cdot 2$ & 1.0000 & 0.9 \\
\hline 10 & $8 \cdot 5$ & 11.9 & 0.5454 & 1.5 \\
\hline 11 & $5 \cdot 4$ & $2 \cdot 4$ & 0.6811 & 0.4 \\
\hline 23 & $19 \cdot 4$ & $19 \cdot 1$ & 1.0000 & $1 \cdot 0$ \\
\hline 24 & $4 \cdot 0$ & 11.9 & 0.0671 & 3.4 \\
\hline 26 & $7 \cdot 0$ & 11.9 & 0.3360 & 1.8 \\
\hline 28 & $17 \cdot 8$ & $23 \cdot 8$ & 0.3788 & $1 \cdot 4$ \\
\hline 29 & $10 \cdot 1$ & $7 \cdot 1$ & 0.7636 & 0.7 \\
\hline 30 & $22 \cdot 5$ & $19 \cdot 1$ & 0.8294 & 0.8 \\
\hline 31 & $6 \cdot 2$ & $7 \cdot 1$ & 0.7324 & $1 \cdot 2$ \\
\hline 32 & $7 \cdot 0$ & $9 \cdot 5$ & 0.7375 & $1 \cdot 4$ \\
\hline 33 & $11 \cdot 0$ & $11 \cdot 9$ & 0.7848 & $1 \cdot 1$ \\
\hline 34 & $4 \cdot 0$ & $2 \cdot 4$ & $1 \cdot 0000$ & 0.6 \\
\hline 36 & $3 \cdot 1$ & 11.9 & $0.0411 *$ & $4 \cdot 2$ \\
\hline \multicolumn{5}{|l|}{ HLA-B } \\
\hline 5 & $12 \cdot 4$ & 11.9 & $1 \cdot 0000$ & $1 \cdot 0$ \\
\hline 7 & $20 \cdot 2$ & $23 \cdot 8$ & 0.6644 & $1 \cdot 2$ \\
\hline 8 & $6 \cdot 2$ & $26 \cdot 2$ & $0.0010^{* * *}$ & $5 \cdot 4$ \\
\hline 12 & $23 \cdot 3$ & $14 \cdot 3$ & $0 \cdot 2779$ & 0.6 \\
\hline 13 & $2 \cdot 3$ & 0.0 & 1.0000 & 0.0 \\
\hline 14 & $6 \cdot 2$ & $7 \cdot 1$ & 0.7324 & $1 \cdot 2$ \\
\hline 15 & $9 \cdot 3$ & 0.0 & $0.0399 *$ & 0.0 \\
\hline 16 & $4 \cdot 7$ & $7 \cdot 1$ & 0.6906 & 1.6 \\
\hline 17 & $24 \cdot 0$ & $16 \cdot 7$ & 0.3957 & 0.6 \\
\hline 11 & $8 \cdot 6$ & $4 \cdot 8$ & 0.5242 & 0.5 \\
\hline 21 & 7.0 & $7 \cdot 1$ & 1.0000 & $1 \cdot 0$ \\
\hline 22 & $3 \cdot 1$ & $4 \cdot 8$ & 0.6362 & 1.6 \\
\hline 27 & $5 \cdot 4$ & $7 \cdot 1$ & $0 \cdot 7087$ & $1 \cdot 3$ \\
\hline 35 & $26 \cdot 4$ & $16 \cdot 7$ & 0.2206 & 0.6 \\
\hline 37 & 0.8 & $2 \cdot 4$ & 0.4320 & $3 \cdot 1$ \\
\hline 33 & 1.6 & 0.0 & $1 \cdot 0000$ & 0.0 \\
\hline 39 & 1.6 & $7 \cdot 1$ & 0.0958 & $4 \cdot 9$ \\
\hline 40 & $4 \cdot 7$ & $2 \cdot 4$ & $1 \cdot 0000$ & 0.5 \\
\hline 41 & 0.8 & 0.0 & 1.0000 & 0.0 \\
\hline 42 & $7 \cdot 8$ & 11.9 & 0.5292 & 1.6 \\
\hline 44 & $10 \cdot 9$ & $11 \cdot 9$ & $0 \cdot 7848$ & $1 \cdot 1$ \\
\hline 45 & $11 \cdot 6$ & $2 \cdot 4$ & $0 \cdot 1229$ & $0 \cdot 2$ \\
\hline 49 & $3 \cdot 9$ & $7 \cdot 1$ & 0.4077 & 1.9 \\
\hline 50 & 1.6 & 0.0 & 1.0000 & 0.0 \\
\hline 51 & $3 \cdot 9$ & 11.9 & 0.0671 & $3 \cdot 4$ \\
\hline 52 & $5 \cdot 4$ & 0.0 & $0 \cdot 1960$ & 0.0 \\
\hline 53 & 3.9 & $9 \cdot 5$ & 0.2256 & $2 \cdot 6$ \\
\hline 57 & $2 \cdot 3$ & $4 \cdot 8$ & 0.5974 & $2 \cdot 1$ \\
\hline 58 & 0.8 & $7 \cdot 1$ & $0.0463 *$ & 9.9 \\
\hline \multicolumn{5}{|l|}{ HLA-C } \\
\hline 1 & $1 \cdot 6$ & $2 \cdot 4$ & 0.5732 & 1.6 \\
\hline 2 & $17 \cdot 1$ & $14 \cdot 3$ & 0.8122 & 0.8 \\
\hline 3 & $24 \cdot 0$ & 23.8 & 1.0000 & 1.0 \\
\hline 4 & $27 \cdot 9$ & $35 \cdot 7$ & 0.3368 & 0.4 \\
\hline 5 & $1 \cdot 6$ & $0 \cdot 0$ & 0.4170 & $1 \cdot 0$ \\
\hline 6 & 10.9 & $11 \cdot 9$ & 0.8505 & 0.9 \\
\hline
\end{tabular}

and $\mathrm{C}$ antigens by the standard lymphocyte microcytotoxic test. ${ }^{18} \mathrm{~A}$ total of 59 controls and all patients were also tested for HLA DR antigens by the international method. ${ }^{11}$ Briefly, $T$ cells were separated from B cells by rosetting with sheep red blood cells which had been pretreated with 2aminoethylisothiouranium bromide hydrobromide. The $B$ cell suspensions were incubated with $D R$ antisera for 60 minutes at, $37^{\circ} \mathrm{C}$, and after addition of rabbit complement they were further incubated for an additional 120 minutes at $22^{\circ} \mathrm{C}$ prior to addition of eosin and formalin, as described elsewhere. ${ }^{18}$

For comparison of phenotype frequencies between controls and patients the $p$ values were calculated by Fisher's exact method. ${ }^{19}$

\section{Results}

The comparisons of phenotype frequencies of the HLA A, B, and C antigens between the control and the patient groups are presented in Table 1. The phenotype frequency of HLA B8 was greatly increased in patients in comparison with that in the control group (exact $p=0.0010$, relative risk 5.4). Other antigens with an increased incidence included Aw36 (exact $p=0.0411$ ) and Bw58 (exact $p=0.0463$ ), the last with the highest relative risk of 9.9.

Most striking was the almost identical phenotype frequency of B27 found in the patient and the control groups (exact $p=0.7087$ ). Of interest was the relative decrease of certain antigens among patients, particularly HLA B15, present in $9.3 \%$ of the control group, and in none of the patients tested (exact $\mathrm{p}=0.0399$ ).

The comparison of the HLA DR phenotype frequencies in the 2 groups is given in Table 2. No DR antigen was significantly increased in the patients. However, DR5 and DRw8 had somewhat greater frequencies in the patient group.

Table 2 Comparison of the HLA DR phenotypic frequencies (PF) in American blacks with and without iridocyclitis

\begin{tabular}{|c|c|c|c|c|}
\hline \multirow[b]{2}{*}{$\begin{array}{l}B \text { cell } \\
\text { antigen }\end{array}$} & \multicolumn{2}{|l|}{$P F(\%)$} & \multirow[b]{2}{*}{ Exact $p$} & \multirow[b]{2}{*}{ Relative risk } \\
\hline & $\begin{array}{l}\text { Controls } \\
n=59\end{array}$ & $\begin{array}{l}\text { Patients } \\
n=41\end{array}$ & & \\
\hline \multicolumn{5}{|c|}{ HLA DR } \\
\hline 1 & $18 \cdot 6$ & $14 \cdot 6$ & 0.7876 & 0.8 \\
\hline 2 & $32 \cdot 2$ & $43 \cdot 9$ & 0.2934 & 1.7 \\
\hline $\begin{array}{l}3 \\
4\end{array}$ & $\begin{array}{l}30 \cdot 5 \\
15 \cdot 3\end{array}$ & $\begin{array}{l}29 \cdot 3 \\
12 \cdot 2\end{array}$ & $\begin{array}{l}1 \cdot 0000 \\
0.7744\end{array}$ & $\begin{array}{l}0.9 \\
0.8\end{array}$ \\
\hline 5 & $28 \cdot 8$ & $41 \cdot 5$ & 0.2050 & 1.8 \\
\hline 6 & 13.6 & $12 \cdot 2$ & 1.0000 & 0.9 \\
\hline 7 & 28.8 & $12 \cdot 2$ & 0.0540 & 0.3 \\
\hline 8 & 3.4 & $14 \cdot 6$ & 0.0609 & $4 \cdot 9$ \\
\hline
\end{tabular}


Table 3 Comparison of $H L A B 8$ positive and negative black Americans with iridocyclitis

\begin{tabular}{llcc}
\hline & & \multicolumn{2}{c}{ HLA B8 } \\
\cline { 3 - 4 } & & $\begin{array}{l}\text { Positive } \\
n=10\end{array}$ & $\begin{array}{c}\text { Negative } \\
n=31\end{array}$ \\
\hline Sex & Male & 3 & 15 \\
Visual acuity* & Female & 7 & 16 \\
& $20 / 20-40$ & 5 & 7 \\
Age at onset & $20 / 50-80$ & 3 & 15 \\
& $20 / 100-$ LP & 2 & 9 \\
Uveitis & $1-20$ yr & 1 & 1 \\
& $20-40$ yr & 9 & 30 \\
& Bilateral & 10 & 27 \\
& Uniocular & 0 & 4 \\
Disease association & Nongranulomatous & 10 & 23 \\
& Granulomatous & 0 & 8 \\
& None & 0 & 27 \\
& Sarcoid & 0 & 4 \\
\hline
\end{tabular}

*Best visual acuity in worst eye. $\mathbf{L P}=$ perception of light.

In order to characterise the B8 positive uveitis group a comparison of the $\mathrm{B} 8$ positive and negative patients was done (Table 3 ). While the $\mathrm{B} 8$ negative group of patients was evenly divided between male and female, the B8 positive group showed a female predominance. The B8 positive group in addition had no known systemic disease association, and had disease which was bilateral and nongranulomatous in nature. Some patients had a chronic recurrent pattern, while others had an acute recurrent course to their disease. A sizeable proportion of both groups had a noncorrectable drop in visual acuity due to their disease.

\section{Discussion}

In the middle of this century the aetiology of most cases of uveitis was thought to be of an infectious nature. This theory has, at least for many conditions, not survived the years, ${ }^{20}$ and an endogenous cause for ocular inflammatory disease has been proposed. The HLA B8 antigen has previously been associated with a variety of presumed autoimmune conditions, including those with ocular involvement. ${ }^{21-25}$ The finding of $\mathrm{B} 8$ being associated with this disease entity would suggest that this condition may also be of an autoimmune aetiology. Further, this association of HLA B8 antigen to iridocyclitis in black Americans is a strong one (Table 1). The relative risk calculated for this disease, when the antigen is present, is greater than for all well-known B8-associated autoimmune diseases except for coeliac disease and dermatitis herpetiformis. ${ }^{25}$

The B8-associated disease entity reported here is different from the anterior uveitis in Caucasoids associated with B27. Woodrow et al..$^{5}$ reported that the typical B27 uveitis was one found in males, being uniocular and nongranulomatous, having repeated attacks, and usually not leaving visual handicap. The B8 uveitis in black Americans reported here was bilateral, nongranulomatous, more commonly seen in females, and leaving several patients with visual handicap.

The finding of an increase in only B8 in our patients would suggest that this disease propensity centres about this gene locus, and this is perhaps true of some Caucasoids with autoimmune disease. However, antigens A1, B8, and DR3 are known to be in positive linkage disequilibrium among Caucasoids, ${ }^{11}$ and consequently all 3 antigen frequencies may be found elevated in this group. This theory has also been proposed for myasthenia gravis, where the B8 association seems much greater than the DR3 association. ${ }^{26}$ Although several entities of autoimmune origin have been associated with the B8 antigen, this is the first report we are aware of associating B8 with intraocular inflammatory disease. Brewerton et $a .^{27}$ reported that among sarcoid patients, presumably Caucasoid, A1 was increased among those with uveitis, while B8 was elevated in those who had arthritis. None of our B8-positive patients had ocular sarcoid.

The lack of certain antigens in the patient group could be a reflection of the relatively small sample size, with the exception of B15. It has been noted that Caucasoid diabetes mellitus patients bearing B8 and DR3 differ in their immunological response from those patients bearing B15 and DR4. B8, DR3 patients have a higher incidence of anti-B-cell antibodies, while B15, DR4 patients tend to have high antibody titres to exogenous insulin. ${ }^{28} 29$ If found valid in a larger patient sample, an absence of B15 in this disease may suggest an association between $\mathrm{B} 15$ and some factor causing resistance against this disease.

Some of the more commonly proposed roles for HLA in the pathogenesis mechanisms are the following: (1) certain HLA genes act as immune response genes, or they are closely linked to those that are; (2) certain HLA antigens may serve as receptors for pathogens or toxins; (3) certain invading pathogens may 'mimic' specific HLA antigens, thus making 'non-self' appear as 'self', leading to cross-tolerance; and (4) if pathogens or toxins can alter antigens coded for by the HLA loci, this may result in 'altered self', leading to autoimmunity. ${ }^{250}$ Apart from the first hypothesis that the HLA region may include the immune response loci, thereby contributing to the pathogenesis of disease, all other theories propose a role of some exogenous factor. Seager and co-workers ${ }^{31}$ have reported antigenic similarities between the products 
of klebsiella and the B27 associated antigens. This finding may be of importance in understanding the pathophysiology of disease seen in B27-positive patients. Added insight into this type of uveitis has also been gained from the recent finding of an anterior inflammatory response which was induced in animals by immunisation with lipopolysaccharide, a purified component of the cell wall of Gram negative bacteria. ${ }^{32}$

Clues to the role that B8 may play in the pathogenesis of autoimmune disease are not yet evident. As proposed by Strober, ${ }^{33}$ the restricted genotype found in this category of very varied disease presentations suggests a common pathophysiological mechanism acting in conjunction with independent environmental and genetic factors to produce specific disease entities.

The variety of clinical entities which are placed under the diagnosis of uveitis are legion. It is clear that more effective diagnostic and descriptive methods are needed to categorise these diseases. Further studies defining the immunological and nonimmunological characteristics of both the B8associated and nonassociated uveitides may help in defining more precisely this varied and perplexing group of diseases.

We thank the following who were instrumental in completing this study: Drs W. Glew, G. Selby, L. Shiengorn, and S. Scott of the Department of Ophthalmology, Washington Hospital Center, Washington DC; Drs M. Alper, J. Goldman, M. Lemp, W. Morris, E. Titer, and E. Zimmerman, Washington, DC; Dr David Knox, Wilmer Eye Institute, Baltimore, MD.

\section{References}

1 Snell GD, Dausset J, Nathenson S. Histocompatibility. New York: Academic Press, 1976.

2 Brewerton DA, Hart FD, Nicholls A, Caffrey M, James DCO, Sturrock RD. Ankylosing spondylitis and HL-A 27. Lancet 1973; i: 904-7.

3 Schlosstein L, Terasaki PI, Bluestone R, Pearson C. High association of an HL-A antigen -W27, with ankylosing spondylitis. $N$ Engl J Med 1973; 288: 704-6.

4 Brewerton DA, Caffrey M, Nicholls A, Walters D, James DCO. Acute anterior uveitis and HL-A 27. Lancet 1973; ii: $994-6$.

5 Woodrow JC, Mapstone R, Anderson J, Usher N. HL-A27 and anterior uveitis. Tissue Antigens 1975; 6: 116-20.

6 Lenoch F, Kralik V, Bartos J. 'Rheumatic' iritis and iridocyclitis. Ann Rheum Dis 1959; 18: 45-8.

7 Ehlers N, Kissmeyer-Nielsen F, Kjerbye KE, Lamm LU. HL-A27 in acute and chronic uveitis. Lancet 1974; i: 99

8 Ohno S, Char DH, Kimura SJ, O'Connor GR. HLA antigens and antinuclear antibody titers in juvenile chronic iridocyclitis. Br J Ophthalmol 1977; 61 : 59-61.

9 Ohno S, Kimura SJ, O'Connor GR, Char DH. HLA antigens and uveitis. Br J Ophthalmol 1977; 61 : 62-4.

10 Maier G, Miller B, Freedman J, Baumgarten I. HLA antigens in acute anterior uveitis in South African blacks. Br J Ophthalmol 1980; 64: 329-31.
11 Terasaki PI, ed. Histocompatibility Testing 1980. Los Angeles: UCLA Tissue Typing Laboratory, 1980.

12 Feighery C, Stastny P. HLA-D region-associated determinants serve as targets for human cell-mediated lysis. $J$ Exp Med 1979; 149: 485-94.

13 Sonderstrup-Hansen G, Rubin B, Sorensen SF, Svejgaard A. Importance of HLA-D antigens for the cooperation between human monocytes and $\mathrm{T}$ lymphocytes. Eur $J$ Immunol 1978; 8: 520-5.

14 Reinertsen JL, Klippel JH, Johnson AH, Steinberg AD, Decker JL, Mann DL. B-lymphocyte alloantigens associated with systemic lupus erythematosus. $N$ Engl $J$ Med 1978; 299: 515-8.

15 Farid NR, Sampson L, Noel EP, et al. The study of human leucocyte D locus related antigens in Graves's disease. $J$ Clin Invest 1979; 63: 108-13.

16 Meyers-Elliott RH, Elliott JH, Maxwell WA, et al. HLA antigens in recurrent stromal herpes simplex virus keratitis. Am J Ophthalmol 1980; 89: 54-7.

17 Meredith TA, Smith RE, Duquesnoy RJ. Association of HLA-DRw2 antigen with presumed ocular histoplasmosis. Am J Ophthalmol 1980; 89: 70-6.

18 Mittal KK. Standardization of the HLA typing method and reagents. Transplantation 1978; 25 : 275-9.

19 Snedecor GW, Cochran WG. Statistical Methods. Ames: Iowa State University Press, 1967: 217.

20 Woods AC. Endogenous Inflammations of the Uveal Tract. Baltimore: Williams and Wilkins, 1961: 46.

21 Grumet FC, Coukell A, Bodmer JG. Histocompatibility (HL-A) antigens associated with systemic lupus erythematosus: a possible genetic predisposition to disease. $N$ Engl J Med 1971; 287: 193.

22 Irvine WJ, Gray RS, Morris PJ, Ting A. Correlation of HLA and thyroid antibodies with clinical course of thyrotoxicosis treated with antithyroid drugs. Lancet 1977; ii: 898-900.

23 Larkins RG, Martin FIR, Tait BD. HLA patterns and diabetic retinopathy. Br Med J 1978; i: 1111 .

24 Katz P, Alling DW, Haynes BS, Fauci AS. Association of Wegener's granulomatosis with HLA-B8. Clin Immunol Immunopathol 1979; 14: 268-70.

25 Dausset J, Svejgaard A, eds. HLA and Disease. Copenhagen: Munksgaard, 1977: 54-71.

26 Moller E, Hammerstrom L, Smith E, Matell G. HL-A8 and LD-8a in patients with myasthenia gravis. Tissue Antigens 1976; 7: 39-44.

27 Brewerton DA, Cockburn C, James DCO, James DG, Neville E. HLA antigens in sarcoidosis. Clin Exp Immunol 1977; 27 : 227-9.

28 Morris PJ, Vaughan H, Irvine WJ, et al. HLA and pancreatic islet cell antibodies in diabetes. Lancet 1976; ii: 652-3.

29 Betrams J, Jansen FK, Gruneklee D, et al. HLA antigens and immunoresponsiveness to insulin in insulin-dependent diabetes mellitus. Tissue Antigens 1976; 8: 13-9.

30 Albert ED, Gotze D. The major histocompatibility system in man. In: Gotze D, ed. The Major Histocompatibility System in Man and Animals. Berlin: Springer, 1977: 7-77.

31 Seager K, Bashir HV, Geczy AF, Edmonds J, de VereTyndell A. Evidence for a specific B27-associated cell surface marker on lymphocytes of patients with ankylosing spondylitis. Nature $1979 ; 277: 68-70$.

32 Rosenbaum JT, McDevitt HO, Guss RB, Egbert PR. Endotoxin induced uveitis in rats as a model for human disease. Nature 1980; 286: 611-3.

33 Strober W. The current status of associations between major abnormalities of HLA antigen frequency and disease. In: Steinberg CM, Gery I, Nussenblatt RB, eds. Immunology of the Eye, Workshop I, Immunogenetics and Transplantation Immunity. Sp: suppl. Immunology Abstracts, 1980: 43-72. 